\title{
Pseudomonas baetica sp. nov., a fish pathogen isolated from wedge sole, Dicologlossa cuneata (Moreau)
}

Correspondence

Jose R. López

lasacias@yahoo.es

\author{
Jose R. López, ${ }^{1} \dagger$ Ana L. Diéguez, ${ }^{2} \dagger$ Alejandra Doce, ${ }^{2}$ Elena De la Roca, ${ }^{1}$ \\ Roberto De la Herran, ${ }^{3}$ Jose I. Navas, ${ }^{1}$ Alicia E. Toranzo ${ }^{2}$ \\ and Jesus L. Romalde ${ }^{2}$
${ }^{1}$ IFAPA Centro Agua del Pino, Junta de Andalucia, Carretera El Portil-El Rompido s/n, 21450 Cartaya, Huelva, Spain \\ ${ }^{2}$ Departamento de Microbiología y Parasitología, Facultad de Biología e Instituto de Acuicultura, \\ Universidad de Santiago, 15782 Santiago de Compostela, Spain
}

${ }^{3}$ Departamento de Genética, Facultad de Ciencias, Universidad de Granada, 18071 Granada, Spain

Five Gram-negative bacterial isolates, recovered from an outbreak that occurred in March 2006 in Huelva, Spain, affecting adult diseased cultured wedge sole [Dicologlossa cuneata (Moreau)], were characterized phenotypically and genotypically in order to clarify their taxonomic position. On the basis of 16S rRNA gene sequence analysis, the isolates were included in the genus Pseudomonas, within the Pseudomonas fluorescens-related species group, their closest relatives being the Pseudomonas jessenii and Pseudomonas koreensis subgroups. The highest sequence similarities were recorded with the type strains of Pseudomonas reinekei, $P$. moorei,

$P$. umsongensis, $P$. jessenii and P. mohnii (99.4-99.3\% similarity). Sequence analysis of the housekeeping genes gyrB and $r p o D$ clearly differentiated the isolates from currently described Pseudomonas species, the highest sequence similarities recorded to type strains being below $95 \%$ for both genes. Phylogenetic analysis using concatenated sequences of the three genes showed Pseudomonas moraviensis DSM $16007^{\top}$ and $P$. koreensis DSM $16610^{\top}$ as the closest reference strains. DNA-DNA hybridization assays with related strains confirmed that these isolates belong to a novel species of the genus Pseudomonas, for which the name Pseudomonas baetica sp. nov. is proposed. The type strain is strain $\mathrm{a} 390^{\top}\left(=\right.$ CECT $7720^{\top}=$ LMG $\left.25716^{\top}\right)$. The novel species could be easily distinguished from phylogenetically related species by several phenotypic characteristics, including gelatin hydrolysis, acid production from glucose and growth at $6 \% \mathrm{NaCl}$. Virulence assays revealed that the novel species is pathogenic for wedge sole.
Pseudomonas Migula 1894 is a genus of gammaproteobacteria that belongs to the family Pseudomonadaceae. These Gram-negative rods display great metabolic diversity that enables them to utilize a wide range of organic compounds and they occupy an important ecological position in the

†These authors contributed equally to this work.

The GenBank/EMBL/DDBJ accession numbers for the $16 \mathrm{~S}$ rRNA, gyrB and $r p o D$ gene sequences of strains $a 390^{\top}$, a391, a393, a398 and a399 are respectively FM201274, FM201278 and FN678357 (a390'); FM201275, FM201279 and FN678358 (a391); FN678353, FN678354 and FN678359 (a393); FM201276, FN678355 and FN678360 (a398); and FM201277, FN678356 and FN678361 (a399). Those for the rpoD gene sequences of $P$. jessenii DSM $17150^{\top}, P$. reinekei DSM $18361^{\top}$ and $P$. moorei DSM $12647^{\top}$ are respectively FN678364, FN678362 and FN678363.

Four supplementary figures and a supplementary table are available with the online version of this paper. carbon cycle. Pseudomonads are ubiquitous, being found in a diverse range of ecosystems, and are also important as pathogens of animals and plants (Tryfinopoulou et al., 2002; Bossis et al., 2000; Yamamoto et al., 2000). The genus has undergone repeated taxonomic revision. DNA-rRNA hybridization experiments carried out by Palleroni et al. (1973) showed that the genus Pseudomonas, as classically defined, in fact consisted of a conglomeration of genera that could be separated clearly into five rRNA similarity groups. Nowadays, only rRNA group I, which contains the type species Pseudomonas aeruginosa, is considered the 'true' genus Pseudomonas or Pseudomonas sensu stricto, while the members of the other groups have been reclassified into newly created genera. The genus Pseudomonas sensu stricto, composed of several groups, includes both fluorescent and non-fluorescent species (Kersters et al., 1996; Anzai et al., 1997; Verhille et al., 1999b; Scarpellini et al., 2004). 
According to this classification, some Pseudomonas species have been reported to be causative agents of fish disease. Among these, Pseudomonas anguilliseptica is considered the most significant for cultured fish, having been described from many species, including turbot (Toranzo et al., 2005). However, other species of the genus may also be serious pathogens, such as Pseudomonas plecoglossicida in ayu, Pseudomonas chlororaphis in amago trout, $P$. aeruginosa in South-American catfish, Pseudomonas putida in ayu, rainbow trout and yellowtail and Pseudomonas fluorescens in carp, sea bream and tilapia (Austin \& Austin, 2007). The present paper reports the description of Pseudomonas baetica sp. nov., a novel fish pathogen isolated from wedge sole [Dicologlossa cuneata (Moreau)], an economically valuable flatfish species that is being cultured in south-west Spain in order to diversify marine aquaculture.

Samples for bacterial isolation were taken from livers of moribund wedge sole and cultured on Flexibacter maritimus medium (FMM) (Pazos et al., 1996) at $20{ }^{\circ} \mathrm{C}$ for $24-96 \mathrm{~h}$. Isolates were subcultured onto tryptic soy agar (TSA; Difco). Strains were stored in sterile seawater containing $20 \%$ glycerol at $-80{ }^{\circ} \mathrm{C}$. The Gram reaction was determined according to the $\mathrm{KOH}$ method proposed by Buck (1982) and by the Gram-staining method. To investigate physiological and biochemical characteristics, we used the methods proposed by Smibert \& Krieg (1981) for the following tests: motility, cytochrome oxidase, catalase, oxidation/fermentation (OF), arginine dihydrolase, decarboxylation of lysine and ornithine (Moeller's method), reduction of nitrate, Simmons' citrate, indole production, acid production from lactose, mannose and salicin and the extracellular enzyme activities urease, caseinase, gelatinase, lipase (Tween 80) and amylase and hydrolysis of aesculin. Gas production from glucose was tested according to MacFaddin (1980). Temperature tolerance was tested by checking growth on TSA at $4,30,35,40$ and $44{ }^{\circ} \mathrm{C}$ and tolerance of salinity was tested with growth on nutrient agar supplemented with $0,3,6,8,10$ and $12 \%(w / v) ~ N a C l$. Growth on thiosulfate-citrate-bile salts-sucrose (TCBS) agar (Difco) was also tested. Fluorescein and pyocyanin production was tested on King media B and A (King et al., 1954), respectively. Haemolysis activity was assayed on Columbia agar with $5 \%$ sheep blood (BD-BBL). All tests were incubated aerobically at $20{ }^{\circ} \mathrm{C}$. Commercial miniaturized API 20E, API 20NE and API ZYM galleries (bioMérieux) were also utilized according to the manufacturer's instructions, with incubation at $20{ }^{\circ} \mathrm{C}$. Carbon utilization tests were carried out using Biolog GN2 MicroPlates as described in the manufacturer's manual. The reference strains $P$. aeruginosa ATCC 27853, P. fluorescens CECT $378^{\mathrm{T}}$ and P. putida CECT 385 were included as controls to determine the specificity of the identification system. Drug sensitivity of the isolates was determined on Mueller-Hinton agar by the disc diffusion method using the following chemotherapeutic agents ( $\mu \mathrm{g}$ per disc; Oxoid): ampicillin (10), novobiocin (30) and the vibriostatic agent $\mathrm{O} / 129$ (10 and 150). Antibiogram readings were performed after $48 \mathrm{~h}$ incubation at $20{ }^{\circ} \mathrm{C}$. Strains with inhibition diameters greater than $1.5 \mathrm{~cm}$ were considered as susceptible.

Five strains $\left(\mathrm{a} 390^{\mathrm{T}}\right.$, a391, a393, a398 and a399) were isolated from the livers of several cultivated adult wedge sole during an outbreak with a moderate mortality rate that occurred in an experimental marine farm located in Huelva, in southwest Spain, in March 2006. Although they were dying, the fish showed no external or internal signs of disease. On the basis of morphological, physiological and biochemical characteristics, pure cultures of the isolates were tentatively included in the genus Pseudomonas. All the strains were Gram-negative, oxidase-positive, motile, strictly aerobic, large irregular rods, able to grow in $0-6 \% \mathrm{NaCl}$ at $4-30{ }^{\circ} \mathrm{C}$. They were also positive for arginine dihydrolase, gelatinase, fluorescein production and denitrification. Other tests carried out are summarized in the species description. Altogether, the five isolates examined were phenotypically homogeneous, showing only minor discrepancies. The API 20E, API ZYM and Biolog profiles were identical for all five strains except for the results of one (acid from melibiose), three (alkaline phosphatase, esterase $\mathrm{C} 4$ and leucine arylamidase) and five (utilization of monomethyl succinate, L-histidine, L-threonine, putrescine and 2-aminoethanol) tests, respectively. According to the Biolog MicroLog3 software, all five isolates were identified as $P$. fluorescens biotype G. However, no amplification fragment was obtained when primers 16SPSEfluF and 16SPSER were used, designed to recognize all P. fluorescens biotypes (Scarpellini et al., 2004). On the other hand, several differentiating phenotypic characteristics were found between these strains and closely related Pseudomonas species (Table 1). The most discriminatory tests were hydrolysis of gelatin, acid production from glucose, growth at $6 \% \mathrm{NaCl}$, absence/presence of fluorescein and utilization as a sole carbon source of $\mathrm{N}$-acetyl-D-glucosamine, formic acid, D-galacturonic acid, D-glucosaminic acid, hydroxyl-Lproline, inosine and uridine.

Since it has been reported recently by Mulet et al. (2010) that analysis of three concatenated gene sequences (16S rRNA, gyrB and $r p o D$ ) is sufficient for reliable phylogenetic analysis of the genus Pseudomonas, this approach was employed here. For 16S rRNA gene and housekeeping gene sequence analysis, DNA was extracted from a single bacterial colony by boiling for $10 \mathrm{~min}$ in distilled water and quantified by spectrophotometry $\left(A_{260}\right)$. Partial $16 \mathrm{~S}$ rRNA, gyrB and $r p o D$ gene sequences were obtained using universal primers $20 \mathrm{~F}$ and 1500R, described by Kawasaki et al. (1993), UP1 and UP2r, described by Yamamoto \& Harayama (1995), and 70F and 70R, described by Yamamoto \& Harayama (1998), respectively. The PCR products were purified with the GenElute PCR Clean-up kit (Sigma) and sequenced directly using an ABI Prism 373A DNA Sequencer (Applied Biosystems). PCRs and sequencing were performed generally as indicated in the literature in each case. Sequencing of the $r p o D$ gene was also performed for the type strains of Pseudomonas jessenii, Pseudomonas reinekei and Pseudomonas moorei, since these sequences were absent from the GenBank/ EMBL databases. Sequence corrections and analysis were 
Table 1. Characteristics that differentiate Pseudomonas baetica sp. nov. from closely related Pseudomonas species

Species: 1, P. baetica sp. nov.; 2, P. moorei; 3, P. umsongensis; 4, P. mohnii; 5, P. reinekei; 6, P. jessenii; 7, P. fluorescens; 8, P. koreensis; 9, $P$. moraviensis. Data were taken from Verhille et al. (1999a, b), Kwon et al. (2003), Buller (2004), Tvrzová et al. (2006), Cámara et al. (2007) and this work.,$+ 90 \%$ or more strains positive; $\mathrm{V}+, 75-89 \%$ strains positive; $v, 26-74 \%$ strains positive; $v-, 11-25 \%$ strains positive; -, $0-10 \%$ strains positive; $(+)$, weak positive reaction; ND, no data available.

\begin{tabular}{|c|c|c|c|c|c|c|c|c|c|}
\hline Characteristic & 1 & 2 & 3 & 4 & 5 & 6 & 7 & 8 & 9 \\
\hline Arginine dihydrolase & + & + & + & + & - & - & + & + & - \\
\hline Nitrate reduction & - & - & + & - & - & + & $\mathrm{v}$ & - & - \\
\hline \multicolumn{10}{|l|}{ Hydrolysis of: } \\
\hline Tween 80 & - & - & - & - & - & - & $\mathrm{ND}$ & + & ND \\
\hline Gelatin & + & - & - & - & - & - & + & $\mathrm{v}+$ & + \\
\hline Casein & + & $\mathrm{ND}$ & $\mathrm{ND}$ & $\mathrm{ND}$ & $\mathrm{ND}$ & + & ND & - & - \\
\hline Acid from glucose & + & - & - & - & - & $\mathrm{ND}$ & + & - & - \\
\hline Growth at $6 \% \mathrm{NaCl}$ & + & - & - & - & - & - & ND & $\mathrm{ND}$ & $\mathrm{ND}$ \\
\hline Fluorescein production & + & - & + & - & - & + & + & + & + \\
\hline \multicolumn{10}{|l|}{ Utilization of: ${ }^{\star}$} \\
\hline Tween 40 & + & - & + & - & - & + & + & + & + \\
\hline Tween 80 & + & - & + & - & - & + & + & + & + \\
\hline $\begin{array}{l}N \text {-Acetyl-D- } \\
\text { glucosamine }\end{array}$ & + & - & - & - & -( & $(+)$ & + & + & ND \\
\hline L-Arabinose & + & + & + & + & + & + & + & + & + \\
\hline D-Arabitol & + & - & $\mathrm{V}$ & - & + & + & + & + & + \\
\hline D-Fructose & + & - & + & - & - & + & + & + & + \\
\hline D-Galactose & + & + & + & + & + & + & + & + & + \\
\hline D-Mannitol & + & + & $\mathrm{V}$ & + & - & + & + & + & + \\
\hline D-Mannose & + & - & + & $(+)$ & - & + & + & + & + \\
\hline D-Psicose & - & - & $\mathrm{V}$ & - & - & - & - & - & + \\
\hline Trehalose & - & - & - & - & - & - & + & - & + \\
\hline Acetic acid & + & - & + & - & + & + & + & + & + \\
\hline Formic acid & - & - & + & $(+)$ & + & + & - & - & + \\
\hline $\begin{array}{l}\text { D-Galactonic acid } \\
\text { lactone }\end{array}$ & + & + & + & + & + & + & + & + & + \\
\hline D-Galacturonic acid & - & + & + & + & + & - & + & $\mathrm{V}$ & - \\
\hline D-Glucosaminic acid & - & + & + & $(+)$ & $(+)$ & - & + & + & + \\
\hline D-Glucuronic acid & - & + & $\mathrm{v}$ & + & - & - & + & $\mathrm{V}$ & - \\
\hline$\alpha$-Hydroxybutyric acid & - & - & + & -( & $(+)$ & - & + & + & + \\
\hline \multicolumn{10}{|l|}{$\begin{array}{l}\text { Hydroxyphenylacetic } \\
\text { acid }\end{array}$} \\
\hline$\alpha$-Ketobutyric acid & - & - & + & - & - & - & + & $\mathrm{V}$ & ND \\
\hline$\alpha$-Ketoglutaric acid & + & + & + & + & + & + & + & - & + \\
\hline$\alpha$-Ketovaleric acid & - & - & + & - & -( & $(+)$ & - & + & + \\
\hline Malonic acid & + & - & + & $(+)$ & $(+)$ & + & + & + & + \\
\hline Propionic acid & + & - & + & $(+)$ & $(+)$ & + & + & + & + \\
\hline Quinic acid & + & + & + & + & + & + & + & + & + \\
\hline D-Saccharic acid & + & + & + & + & + & + & + & + & + \\
\hline Succinamic acid & - & - & - & - & - & + & + & - & + \\
\hline Glucuronamide & - & - & - & - & - & - & + & + & ND \\
\hline L-Alaninamide & - & - & + & -( & $(+)$ & + & - & + & + \\
\hline D-Alanine & + & $(+)$ & + & + & - & + & + & + & + \\
\hline L-Alanyl glycine & + & - & + & - & - & + & + & + & + \\
\hline Glycyl L-glutamic acid & - & - & + & - & - & - & + & + & ND \\
\hline
\end{tabular}

Table 1. cont.

\begin{tabular}{|lccccccccc|}
\hline Characteristic & $\mathbf{1}$ & $\mathbf{2}$ & $\mathbf{3}$ & $\mathbf{4}$ & $\mathbf{5}$ & $\mathbf{6}$ & $\mathbf{7}$ & $\mathbf{8}$ & $\mathbf{9}$ \\
\hline L-Histidine & $\mathrm{v}+\dagger$ & + & + & - & - & + & + & + & + \\
Hydroxy-L-proline & - & + & $\mathrm{V}$ & + & - & + & - & + & + \\
L-Leucine & + & - & + & - & - & + & + & + & + \\
L-Ornithine & - & - & + & - & - & + & + & + & - \\
L-Pyroglutamic acid & + & + & + & - & + & + & + & $\mathrm{V}$ & + \\
L-Threonine & $\mathrm{V}+$ & - & + & - & - & + & + & + & + \\
$\gamma$-Aminobutyric acid & + & + & + & + & - & + & + & + & + \\
Inosine & + & - & - & - & - & - & + & + & + \\
Uridine & + & - & - & - & - & - & + & + & + \\
Phenylethylamine & - & - & + & $(+)$ & + & + & - & - & - \\
Putrescine & $\mathrm{V}+\dagger(+)$ & + & $(+)$ & - & + & + & + & $\mathrm{ND}$ \\
2-Aminoethanol & $\mathrm{V}+\dagger(+)$ & + & - & $(+)$ & + & + & + & + \\
DL- $\alpha$-Glycerol & - & - & - & - & - & + & + & - & + \\
phosphate & & & & & & & & & \\
& & & & & & & & & \\
\hline
\end{tabular}

${ }^{\star}$ Data for utilization of substrates as carbon sources for $P$. jessenii and $P$. fluorescens were obtained in this work using the type strains of these species.

$\dagger$ Type strain negative.

performed with the DNASTAR Seqman program (Lasergene). Sequences of phylogenetically related species were obtained after BLAST (http://blast.ncbi.nlm.nih.gov/) and EzTaxon (http://www.eztaxon.org/; Chun et al., 2007) searches. Phylogenetic trees were reconstructed using the neighbourjoining and maximum-likelihood algorithms (Tamura et al., 2007; Posada, 2008; FigTree version 1.1.2, http://tree.bio.ed. ac.uk/). Distance matrices were calculated using Kimura's two-parameter correction. Stability of groupings was estimated by bootstrap analysis (1000 replicates) using the program MEGA version 4.0 (Tamura et al., 2007).

Phylogenetic analysis based on 16S rRNA gene sequences placed the isolates in rRNA group I (Pseudomonas sensu stricto), specifically within the $P$. fluorescens-related species group, their closest relatives being the Pseudomonas jessenii and Pseudomonas koreensis subgroups. However, all the strains were clearly differentiated from other Pseudomonas species, grouping in a separate cluster (Figs 1 and S1, available in IJSEM Online). According to the EzTaxon database, the closest relatives were $P$. jessenii CIP $105274^{\mathrm{T}}$ ( $99.5 \%$ similarity), $P$. moorei DSM $12647^{\mathrm{T}}(99.4 \%)$, P. reinekei DSM $18361^{\mathrm{T}}$ (99.3\%), P. umsongensis KACC $10847^{\mathrm{T}}(99.3 \%)$, P. mohnii DSM $18327^{\mathrm{T}}(99.3 \%)$, P. moraviensis DSM $16007^{\mathrm{T}}(99.2 \%)$, and P. koreensis DSM $16610^{\mathrm{T}}(99.2 \%)$. When using BLAST, the type strains Pseudomonas vancouverensis DSM $17555^{\mathrm{T}}$ and $P$. migulae CIP $105470^{\mathrm{T}}$ and reference strains $P$. fluorescens ATCC 17573, P. fluorescens Pf0-1 and P. putida ATCC 17522 also showed similarity above the limit of intraspecific variability (98.7\%) proposed by Stackebrandt \& Ebers (2006). Nevertheless, in previous studies of the genus Pseudomonas, it has been shown that strains with 16S rRNA gene sequence similarities greater than even $99 \%$ may belong to different species (Uchino et al., 2001; Behrendt et al., 2003; Hauser et al., 


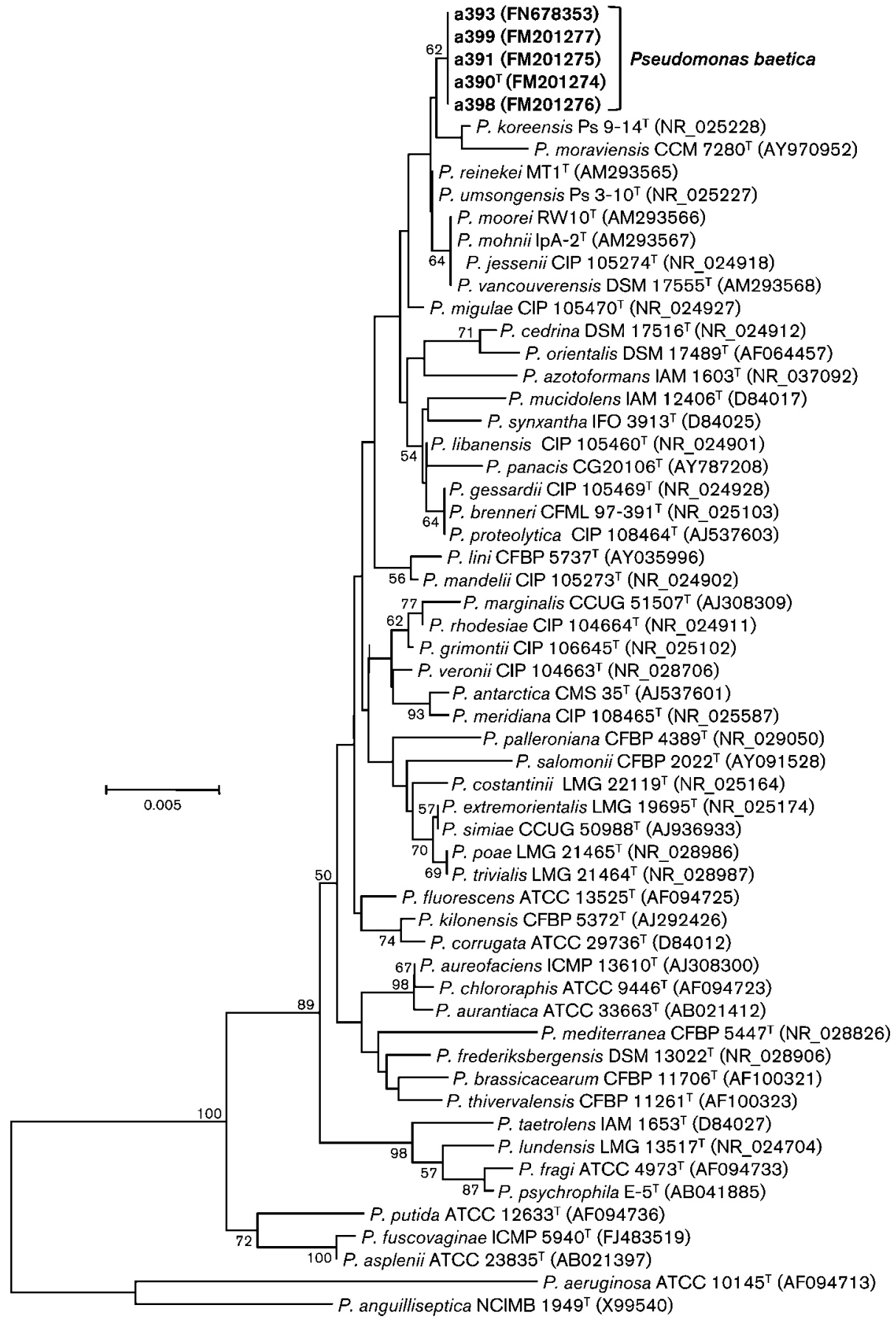

Fig. 1. Neighbour-joining phylogenetic tree based on 16S rRNA gene sequences showing the relationships between strains of

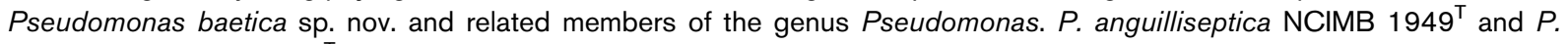
aeruginosa ATCC $10145^{\top}$ were used as an outgroup. The stability of groupings was estimated by bootstrap analysis of 1000 replicates; numbers at nodes show percentage bootstrap values. Similar tree topology was obtained with the maximumlikelihood algorithm (Fig. S1). Bar, 0.005 substitutions per nucleotide position.

2004). Sequence similarities between the five wedge-sole isolates under study were $99.9-100 \%$.

Phylogenetic analyses based on housekeeping genes were more discriminative. The highest similarities between gyrB gene sequences were to Pseudomonas marginalis ATCC $10844^{\mathrm{T}}(94.6 \%)$, P. fluorescens ATCC 17467 (94.5\%), P. fluorescens Pf0-1 (93.8\%) and P. koreensis DSM $16610^{\mathrm{T}}$ (93.4\%), other strains showing values below $93 \%$. The phylogenetic tree derived from these sequences illustrates 
the position of the five isolates under study, clearly separated from other Pseudomonas species (Fig. S2). gyrB gene sequence analysis is considered a highly reliable tool for bacterial species determination (Harayama \& Yamamoto, 1996; Yamamoto \& Harayama, 1996, 1998; Yamamoto et al., 1999, 2000; Soler et al., 2004; Zeigler, 2003). In fact, there is a high correlation between phylogenetic distance based on gyrB sequences and total genome relatedness as analysed by DNA-DNA hybridization, the limit for intraspecific variability being 0.041 (Yamamoto et al., 1999). The genetic distance of the five isolates under study was $0.000-0.004$, showing values with other related strains above 0.060 . According to $r p o D$ gene sequences, the closest relatives were P. fluorescens ATCC 17573 (95.1\% similarity) and Pf0-1 (91.3\%), P. moraviensis LMG $24280^{\mathrm{T}}(92.5 \%)$ and $P$. koreensis LMG $21318^{\mathrm{T}}(91.4 \%)$, other strains displaying similarity of $90 \%$ or lower. The phylogenetic tree derived from $r p o D$ sequences is shown in Fig. S3.

Phylogenetic trees based on concatenated sequences of the $16 \mathrm{~S}$ rRNA gene and the two housekeeping genes ( $g y r B$ and $r p o D$ ) confirmed the clustering of the five isolates with high bootstrap values and their distinction from currently known Pseudomonas species (Figs 2 and S4). Concatenated sequences of the five isolates shared $99.6-100 \%$ similarity. The closest type strains were P. moraviensis DSM $16007^{\mathrm{T}}$ and P. koreensis DSM $16610^{\mathrm{T}}(95.7 \%)$. The reference strain $P$. fluorescens ATCC 17573 also showed high similarity (96.5\%), but the $P$. fluorescens type strain did not (93.7\%). Nevertheless, all these strains showed similarity with 107 Pseudomonas species below the limit of intraspecific variability (97\%) observed by Mulet et al. (2010) using the same three genes. In addition, our results suggest that some reference strains of $P$. fluorescens (Pf0-1 and ATCC 17573) are misidentified, supporting previous findings (Goris et al., 2007; Mulet et al., 2010).

For DNA-DNA hybridization assays, DNA was extracted with the DNeasy Blood \& Tissue kit (Qiagen) and the concentration and purity of each sample were determined by measuring the $A_{260}$ and $A_{260} / A_{280}$ ratio, respectively. DNADNA hybridization assays were performed by the plate method proposed by Ziemke et al. (1998), combining the hydroxyapatite method with non-radioactive detection of released DNA. The hybridization temperature $\left(T_{\mathrm{m}}\right)$ was $65{ }^{\circ} \mathrm{C}$. Levels of DNA-DNA relatedness were determined between strain $\mathrm{a} 390^{\mathrm{T}}$ and the other four isolates and the type strains $P$. moraviensis LMG $24280^{\mathrm{T}}$, $P$. koreensis LMG $21318^{\mathrm{T}}, P$. jessenii DSM $17150^{\mathrm{T}}$, P. reinekei DSM $18361^{\mathrm{T}}$, P. moorei DSM $12647^{\mathrm{T}}$, P. migulae DSM $17966^{\mathrm{T}}$ and $P$. fluorescens ATCC $13525^{\mathrm{T}}$. In addition, reciprocal hybridizations were performed with the most closely related type strains.

DNA-DNA hybridization experiments with other Pseudomonas type strains, selected by consideration of phenotypic and gene sequence analysis, were done in duplicate and confirmed the results obtained previously. Levels of DNA reassociation between strain $\mathrm{a} 390^{\mathrm{T}}$ and the reference
Pseudomonas strains were all less than the threshold value for species delineation of $70 \%$ (Wayne et al., 1987) and ranged from $39.4 \pm 4.5$ to $60.4 \pm 1.4 \%$ (Table 2). Values obtained in reciprocal hybridizations were 44.7, 45.3, 45.3 and $47.6 \%$ for the type strains of $P$. reinekei, $P$. migulae, $P$. jessenii and $P$. moorei, respectively. The DNA-DNA hybridization values with the other four wedge-sole isolates were above this value and ranged from 74 to $96 \%$, proving that these isolates belong to a unique species (Table 2).

Preparation of fatty acid methyl esters (FAMEs) from strain $\mathrm{a} 390^{\mathrm{T}}$ and the type strains of its closest relatives grown at $25{ }^{\circ} \mathrm{C}$ on TSA-1 plates was performed according to the instructions of the Microbial Identification System (MIDI) as described by Sasser (1990). FAMEs were analysed by gas chromatography in an Agilent 6850 GC system equipped with a split injector, flame-ionization detector and a fused silica column $(30 \mathrm{~m} \times 0.2 \mathrm{~mm} \times 0.33 \mathrm{~mm})$. The operating system was Chemstation (Agilent) and Sherlock MIS 6.0 (MIDI) and the aerobic bacteria library TSBA6/RTSBA6.10 was utilized as the MIDI database. The temperature program ramped from 170 to $288{ }^{\circ} \mathrm{C}$ at $28{ }^{\circ} \mathrm{C} \mathrm{min}{ }^{-1}$ with a split ratio of $40: 1$ and head pressure of $144.8 \mathrm{kPa}$. FAME analysis was conducted on three samples of each strain, cultured and treated under identical conditions. FAME composition was consistent with previously published results for members of the genus Pseudomonas (Pseudomonas rRNA group I; Cámara et al., 2007), with saturated and unsaturated $C_{16}$ and $\mathrm{C}_{18}$ fatty acids being the predominant compounds (Table S1). Discrimination fell at the level of 2-OH, 3-OH and $17: 0$ cyclo $\omega 7 c$ fatty acids, as demonstrated previously for species within this group (Cámara et al., 2007). The considerable amount of 12:0 fatty acids and the detection of only trace amounts of $14: 0$ fatty acids supported the inclusion of strain $\mathrm{a} 390^{\mathrm{T}}$, together with its closest neighbours, within intragenic cluster II defined by Yamamoto et al. (2000).

The virulence of strain $\mathrm{a} 390^{\mathrm{T}}$, selected for experimental infections, was tested by two routes of infection: intraperitoneal injection and immersion. Two groups of 10 healthy wedge sole, weighing approximately 2 and $15 \mathrm{~g}$, were challenged by intraperitoneal injection with $10^{6}$ cells per fish, while two other groups of 10 fish weighing approximately $4 \mathrm{~g}$ were challenged by bath immersion for $18 \mathrm{~h}$, as described previously by Avendaño-Herrera et al. (2006), with a bacterial suspension of $10^{7}$ cells $\mathrm{ml}^{-1}$. A control group of 10 fish (challenged with PBS) was included in each virulence assay. After bacterial challenge, experimental and control fish were kept in $18 \mathrm{l}$ tanks at $20^{\circ} \mathrm{C}$ in continually flowing seawater and mortalities were recorded daily for 18 days. Dead fish were removed and subjected to standard bacteriological examination. The Ethics Committee for Animal Experiments of the University of Santiago de Compostela approved the protocols of this study.

Strain $3390^{\mathrm{T}}$ caused significant mortality to wedge sole by intraperitoneal injection $(100 \%$ mortality 3 days after exposure) but not by bath immersion (10\% mortality within 18 days). Experimentally infected fish did not show 


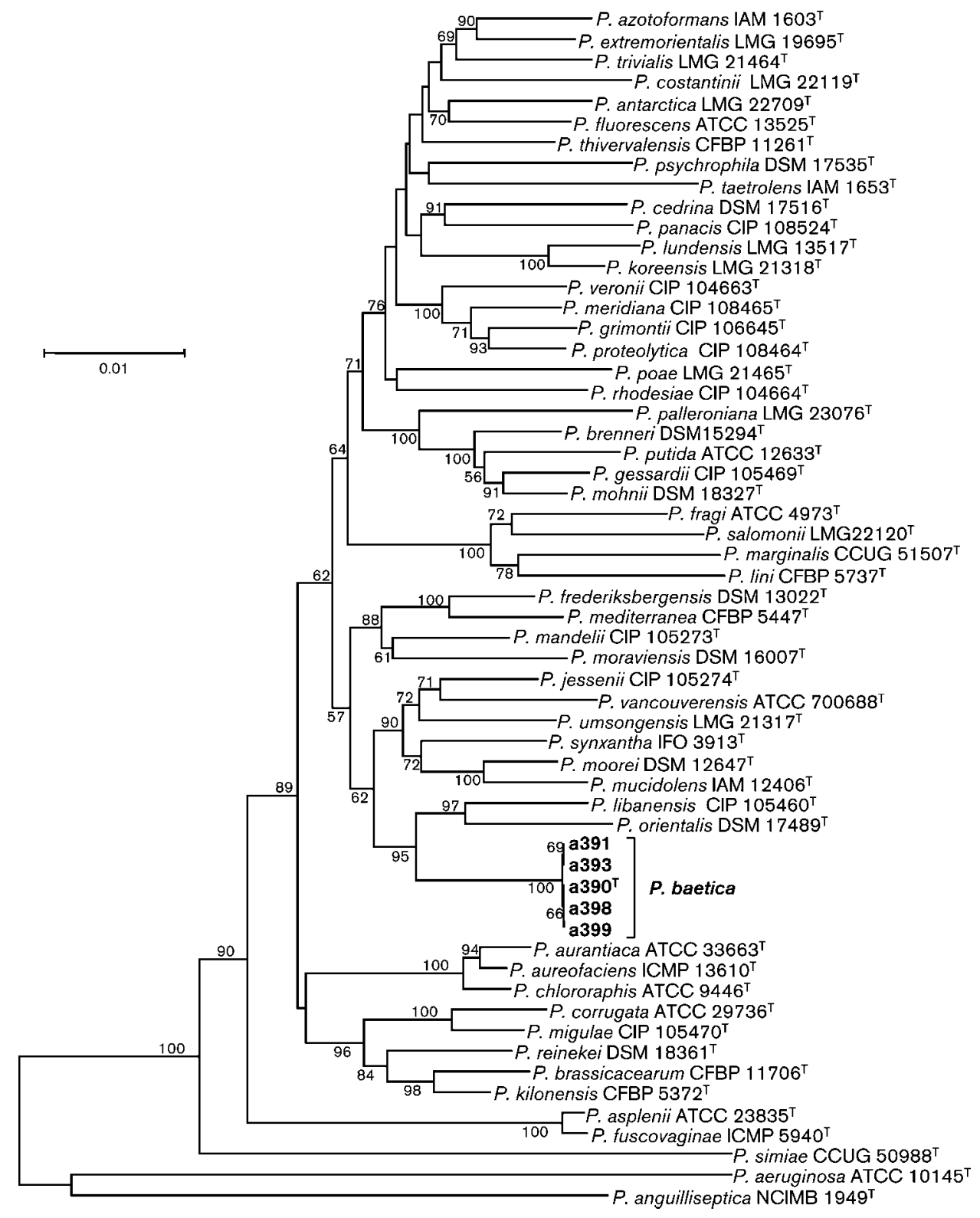

Fig. 2. Neighbour-joining phylogenetic tree based on concatenated sequences of the housekeeping genes gyr $B$ and $r p o D$ and the $16 S$ rRNA gene, showing the position of strains of $P$. baetica sp. nov. $P$. anguilliseptica NCIMB $1949^{\top}$ and $P$. aeruginosa ATCC $10145^{\top}$ were used as an outgroup. The stability of groupings was estimated by bootstrap analysis of 1000 replicates; numbers at nodes show percentage bootstrap values. Similar tree topology was obtained with the maximum-likelihood algorithm (Fig. S4). Bar, 0.01 substitutions per nucleotide position.

clinical signs of disease, but the inoculated strain was recovered from all dead fish. None of the control fish died during the various assays.

In summary, results from phenotypic characterization, $16 \mathrm{~S}$ rRNA and housekeeping gene sequence analysis and DNADNA hybridization confirm that the five wedge-sole isolates represent a novel Pseudomonas species that is pathogenic for fish, for which the name Pseudomonas baetica sp. nov. is proposed, with $\mathrm{a} 390^{\mathrm{T}}$ as the type strain.

\section{Description of Pseudomonas baetica sp. nov.}

Pseudomonas baetica (ba.e'ti.ca. L. fem. adj. baetica of or belonging to Hispania Baetica, the name of the former province of the Roman Empire covering the south-west region of Spain).

Cells are Gram-negative, motile, large irregular rods. Colonies on TSA are small (up to approx. $0.5 \mathrm{~mm}$ in diameter after $48 \mathrm{~h}$ of incubation), round and whitish. Metabolism is oxidative. Cytochrome oxidase and catalase 
Table 2. DNA-DNA hybridization between Pseudomonas baetica sp. nov. $\mathrm{a} 390^{\top}$ and isolates a391, a393, a398 and a399 and type strains of closely related Pseudomonas species

DNA-DNA hybridization experiments performed with type strains of other Pseudomonas species were done in duplicate. Reciprocal values with reference type strains are given in parentheses.

\begin{tabular}{|lc|}
\hline Strain & Hybridization (\%) \\
\hline P. baetica sp. nov. & \\
a390 & $(100)$ \\
a391 & 96 \\
a393 & 84 \\
a398 & 74 \\
a399 & 91 \\
P. moraviensis LMG $24280^{\mathrm{T}}$ & $49.9 \pm 1.0$ \\
P. koreensis LMG $21318^{\mathrm{T}}$ & $46.7 \pm 2.2$ \\
P. moorei DSM $12647^{\mathrm{T}}$ & $60.4 \pm 0.4(47.6)$ \\
P. reinekei DSM $18361^{\mathrm{T}}$ & $60.4 \pm 1.4(44.7)$ \\
P. jessenii DSM $17150^{\mathrm{T}}$ & $57.9 \pm 6.9(45.3)$ \\
P. migulae DSM $17966^{\mathrm{T}}$ & $50.9 \pm 4.1(45.3)$ \\
P. fluorescens ATCC $13525^{\mathrm{T}}$ & $39.4 \pm 4.5$ \\
\hline
\end{tabular}

are produced. Growth occurs at $4-30{ }^{\circ} \mathrm{C}$ in the presence of $0-6 \% \mathrm{NaCl}$. Fluorescein pigment is produced, but pyocyanin is not. Arginine dihydrolase is produced, but lysine and ornithine are not decarboxylated. Nitrate to nitrite reduction test is negative, but denitrification to $\mathrm{N}_{2}$ gas is positive. Does not grow on TCBS agar. Voges-Proskauer, indole and $\mathrm{H}_{2} \mathrm{~S}$ production and ONPG ( $\beta$-galactosidase) tests are negative. Simmons' citrate test is positive. Haemolytic on blood agar. Known strains hydrolyse gelatin and casein, but not starch, Tween 80 , aesculin or urea. Acid is produced from glucose and mannose, but not from mannitol, inositol, sorbitol, rhamnose, sucrose, amygdalin, arabinose, lactose or salicin. Acid production from melibiose is variable (type strain negative). Gas is not produced from glucose. The following substrates are utilized as sole carbon sources for growth (Biolog GN2): Tweens 40 and 80, N-acetyl-Dglucosamine, L-arabinose, D-arabitol, D-fructose, D-galactose, $\alpha$-D-glucose, D-mannitol, D-mannose, methyl pyruvate, acetic acid, cis-aconitic acid, citric acid, D-galactonic acid lactone, D-gluconic acid, $\beta$-hydroxybutyric acid, $\alpha$-ketoglutaric acid, DL-lactic acid, malonic acid, propionic acid, quinic acid, D-saccharic acid, succinic acid, bromosuccinic acid, D- and L-alanine, L-alanyl glycine, L-asparagine, Laspartic acid, L-glutamic acid, L-leucine, L-proline, Lpyroglutamic acid, L-serine, $\gamma$-aminobutyric acid, urocanic acid, inosine, uridine and glycerol. The following substrates are not used: $\alpha$-cyclodextrin, dextrin, glycogen, $N$-acetyl-Dgalactosamine, adonitol, cellobiose, i-erythritol, L-fucose, gentiobiose, myo-inositol, lactose, lactulose, maltose, melibiose, methyl $\beta$-D-glucoside, D-psicose, raffinose, L-rhamnose, D-sorbitol, sucrose, trehalose, turanose, xylitol, formic acid, D-galacturonic acid, D-glucosaminic acid, D-glucuronic acid, $\alpha$-hydroxybutyric acid, $\gamma$-hydroxybutyric acid, $p$ hydroxyphenylacetic acid, itaconic acid, $\alpha$-ketobutyric acid, $\alpha$-ketovaleric acid, sebacic acid, succinamic acid, glucuronamide, L-alaninamide, glycyl L-aspartic acid, glycyl Lglutamic acid, hydroxy-L-proline, L-ornithine, L-phenylalanine, D-serine, DL-carnitine, thymidine, phenylethylamine, 2,3-butanediol, DL- $\alpha$-glycerol phosphate, glucose 1-phosphate and glucose 6-phosphate. Variable results for utilization of L-histidine, L-threonine, putrescine, 2-aminoethanol and monomethyl succinate (type strain negative). The following enzymes are produced (API ZYM): esterase lipase (C8) and acid phosphatase; most strains, including the type strain, produce alkaline phosphatase, esterase $(\mathrm{C} 4)$ and leucine arylamidase but not $\alpha$-fucosidase, lipase (C14), valine arylamidase, cystine arylamidase, trypsin, $\alpha$-chymotrypsin, naphthol-AS-BI-phosphohydrolase, $\alpha$-galactosidase, $\beta$-galactosidase, $\beta$-glucuronidase, $\alpha$-glucosidase, $\beta$-glucosidase, $N$-acetyl- $\beta$-glucosaminidase or $\alpha$-mannosidase. The cellular fatty acid composition is dominated by saturated and unsaturated $\mathrm{C}_{16}$ and $\mathrm{C}_{18}$ fatty acids (type strain profile available in Table $\mathrm{S} 1$ ). Sensitive to ( $\mu \mathrm{g}$ per disc) novobiocin (30) and resistant to the vibriostatic agent $\mathrm{O} / 129$ (10 and 150) and ampicillin (10).

The type strain is a $390^{\mathrm{T}}\left(=\right.$ CECT $7720^{\mathrm{T}}=$ LMG $\left.25716^{\mathrm{T}}\right)$, isolated in 2006 from the liver of a diseased wedge sole on the south-west coast of Spain and pathogenic for this flatfish species. A reference strain is a391 (=CECT 7721 $=\mathrm{LMG}$ 25717), isolated during the same outbreak.

\section{Acknowledgements}

This work was partially funded by the Spanish Ministry of Education and Science (MEC) (INIA research project 2005-00215-C03), the EU FEDER program and the Spanish Ministry of Science and Innovation (MICINN) (grant AGL2010-18438). J.R.L. acknowledges a PhD grant from IFAPA (Junta de Andalucia, Spain).

\section{References}

Anzai, Y., Kudo, Y. \& Oyaizu, H. (1997). The phylogeny of the genera Chryseomonas, Flavimonas, and Pseudomonas supports synonymy of these three genera. Int J Syst Bacteriol 47, 249-251.

Austin, B. \& Austin, D. A. (2007). Bacterial Fish Pathogens: Disease of Farmed and Wild Fish, 4th edn. Chichester: Springer-Praxis.

Avendaño-Herrera, R., Toranzo, A. E. \& Magariños, B. (2006). A challenge model for Tenacibaculum maritimum infection in turbot, Scophthalmus maximus (L.). J Fish Dis 29, 371-374.

Behrendt, U., Ulrich, A. \& Schumann, P. (2003). Fluorescent pseudomonads associated with the phyllosphere of grasses; Pseudomonas trivialis sp. nov., Pseudomonas poae sp. nov. and Pseudomonas congelans sp. nov. Int J Syst Evol Microbiol 53, 14611469.

Bossis, E., Lemanceau, P., Latour, X. \& Gardan, L. (2000). The taxonomy of Pseudomonas fluorescens and Pseudomonas putida: current status and need for revision. Agronomie 20, 51-63.

Buck, J. D. (1982). Nonstaining ( $\mathrm{KOH})$ method for determination of gram reactions of marine bacteria. Appl Environ Microbiol 44, 992993.

Buller, N.B. (editor) (2004). Bacteria from Fish and Other Aquatic Animals: a Practical Identification Manual. Wallingford, UK: CABI Publishing. 
Cámara, B., Strömpl, C., Verbarg, S., Spröer, C., Pieper, D. H. \& Tindall, B. J. (2007). Pseudomonas reinekei sp. nov., Pseudomonas moorei sp. nov. and Pseudomonas mohnii sp. nov., novel species capable of degrading chlorosalicylates or isopimaric acid. Int J Syst Evol Microbiol 57, 923-931.

Chun, J., Lee, J. H., Jung, Y., Kim, M., Kim, S., Kim, B. K. \& Lim, Y. W. (2007). EzTaxon: a web-based tool for the identification of prokaryotes based on $16 \mathrm{~S}$ ribosomal RNA gene sequences. Int J Syst Evol Microbiol 57, 2259-2261.

Goris, J., Konstantinidis, K. T., Klappenbach, J. A., Coenye, T., Vandamme, P. \& Tiedje, J. M. (2007). DNA-DNA hybridization values and their relationship to whole-genome sequence similarities. Int J Syst Evol Microbiol 57, 81-91.

Harayama, S. \& Yamamoto, S. (1996). Phylogenetic identification of Pseudomonas strains based on a comparison of $\operatorname{gyr} B$ and $r p o D$ sequences. In Molecular Biology of Pseudomonas, pp. 250-258. Edited by T. Nakazawa, K. Furukawa, D. Haas \& S. Silver. Washington, DC: American Society for Microbiology.

Hauser, E., Kämpfer, P. \& Busse, H.-J. (2004). Pseudomonas psychrotolerans sp. nov. Int J Syst Evol Microbiol 54, 1633-1637.

Kawasaki, H., Hoshino, Y., Hirata, A. \& Yamasato, K. (1993). Is intracytoplasmic membrane structure a generic criterion? It does not coincide with phylogenetic interrelationships among phototrophic purple nonsulfur bacteria. Arch Microbiol 160, 358-362.

Kersters, K., Ludwig, W., Vancanneyt, M., De Vos, P., Gillis, M. \& Schleifer, K. H. (1996). Recent changes in the classification of the pseudomonads: an overview. Syst Appl Microbiol 19, 465-477.

King, E. O., Ward, M. K. \& Raney, D. E. (1954). Two simple media for the demonstration of pyocyanin and fluorescein. J Lab Clin Med 44, 474-477.

Kwon, S. W., Kim, J. S., Park, I. C., Yoon, S. H., Park, D. H., Lim, C. K. \& Go, S. J. (2003). Pseudomonas koreensis sp. nov., Pseudomonas umsongensis sp. nov. and Pseudomonas jinjuensis sp. nov., novel species from farm soils in Korea. Int J Syst Evol Microbiol 53, 21-27.

MacFaddin, J. F. (1980). Pruebas Bioquímicas para la Identificación de Bacterias de Importancia Clínica. Buenos Aires: Editorial Médica Panamericana (Spanish translation of English original Biochemical Tests for Identification of Medical Bacteria. Baltimore: Lippincott, Williams \& Wilkins)

Migula, W. (1894). Über ein neues System der Bakterien. Arb Bakteriol Inst Tech Hochsch Karlsruhe 1, 235-238 (in German).

Mulet, M., Lalucat, J. \& García-Valdés, E. (2010). DNA sequencebased analysis of the Pseudomonas species. Environ Microbiol 12, 1513-1530.

Palleroni, N. J., Kunisawa, R., Contopoulou, R. \& Doudoroff, M. (1973). Nucleic acid homologies in the genus Pseudomonas. Int J Syst Bacteriol 23, 333-339.

Pazos, F., Santos, Y., Macias, A. R., Nuñez, S. \& Toranzo, A. E. (1996). Evaluation of media for the successful culture of Flexibacter maritimus. J Fish Dis 19, 193-197.

Posada, D. (2008). jModelTest: phylogenetic model averaging. Mol Biol Evol 25, 1253-1256.

Sasser, M. (1990). Identification of bacteria by gas chromatography of cellular fatty acids, MIDI Technical Note 101. Newark, DE: MIDI, Inc.

Scarpellini, M., Franzetti, L. \& Galli, A. (2004). Development of PCR assay to identify Pseudomonas fluorescens and its biotype. FEMS Microbiol Lett 236, 257-260.

Smibert, R. M. \& Krieg, N. R. (1981). General characterization. In Manual of Methods for General Bacteriology, pp. 409-443. Edited by P. Gerhardt, R. G. E. Murray, R. N. Costilow, E. W. Nester,
N. A. Wood, N. R. Krieg \& G. B. Phillips. Washington, DC: American Society for Microbiology.

Soler, L., Yáñez, M. A., Chacon, M. R., Aguilera-Arreola, M. G., Catalán, V., Figueras, M. J. \& Martínez-Murcia, A. J. (2004). Phylogenetic analysis of the genus Aeromonas based on two housekeeping genes. Int J Syst Evol Microbiol 54, 1511-1519.

Stackebrandt, E. \& Ebers, J. (2006). Taxonomic parameters revisited: tarnished gold standards. Microbiol Today 33, 152-155.

Tamura, K., Dudley, J., Nei, M. \& Kumar, S. (2007). MEGA4: molecular evolutionary genetics analysis (MEGA) software version 4.0. Mol Biol Evol 24, 1596-1599.

Toranzo, A. E., Magariños, B. \& Romalde, J. L. (2005). A review of the main bacterial fish diseases in mariculture systems. Aquaculture 246, 37-61.

Tryfinopoulou, P., Tsakalidou, E. \& Nychas, G.-J. E. (2002). Characterization of Pseudomonas spp. associated with spoilage of gilt-head sea bream stored under various conditions. Appl Environ Microbiol 68, 65-72.

Tvrzová, L., Schumann, P., Spröer, C., Sedláček, I., Páčová, Z., Šedo, O., Zdráhal, Z., Steffen, M. \& Lang, E. (2006). Pseudomonas moraviensis sp. nov. and Pseudomonas vranovensis sp. nov., soil bacteria isolated on nitroaromatic compounds, and emended description of Pseudomonas asplenii. Int J Syst Evol Microbiol 56, 2657-2663.

Uchino, M., Shida, O., Uchimura, T. \& Komagata, K. (2001). Recharacterization of Pseudomonas fulva Iizuka and Komagata 1963, and proposals of Pseudomonas parafulva sp. nov. and Pseudomonas cremoricolorata sp. nov. J Gen Appl Microbiol 47, 247261.

Verhille, S., Baida, N., Dabboussi, F., Izard, D. \& Leclerc, H. (1999a). Taxonomic study of bacteria isolated from natural mineral waters: proposal of Pseudomonas jessenii sp. nov. and Pseudomonas mandelii sp. nov. Syst Appl Microbiol 22, 45-58.

Verhille, S., Baïda, N., Dabboussi, F., Hamze, M., Izard, D. \& Leclerc, H. (1999b). Pseudomonas gessardii sp. nov. and Pseudomonas migulae sp. nov., two new species isolated from natural mineral waters. Int J Syst Bacteriol 49, 1559-1572.

Wayne, L. G., Brenner, D. J., Colwell, R. R., Grimont, P. A. D., Kandler, O., Krichevsky, M. I., Moore, L. H., Moore, W. C., Murray, R. G. E. \& other authors (1987). Report of the ad hoc committee on reconciliation of approaches to bacterial systematics. Int J Syst Bacteriol 37, 463-464.

Yamamoto, S. \& Harayama, S. (1995). PCR amplification and direct sequencing of gyrB genes with universal primers and their application to the detection and taxonomic analysis of Pseudomonas putida strains. Appl Environ Microbiol 61, 1104-1109.

Yamamoto, S. \& Harayama, S. (1996). Phylogenetic analysis of Acinetobacter strains based on the nucleotide sequences of $\operatorname{gyrB}$ genes and on the amino acid sequences of their products. Int J Syst Bacteriol 46, 506-511.

Yamamoto, S. \& Harayama, S. (1998). Phylogenetic relationships of Pseudomonas putida strains deduced from the nucleotide sequences of gyrB, rpoD and 16S rRNA genes. Int J Syst Bacteriol 48, 813-819.

Yamamoto, S., Bouvet, P. J. M. \& Harayama, S. (1999). Phylogenetic structures of the genus Acinetobacter based on gyrB sequences: comparison with the grouping by DNA-DNA hybridization. Int J Syst Bacteriol 49, 87-95.

Yamamoto, S., Kasai, H., Arnold, D. L., Jackson, R. W., Vivian, A. \& Harayama, S. (2000). Phylogeny of the genus Pseudomonas: intrageneric structure reconstructed from the nucleotide sequences of gyrB and rpoD genes. Microbiology 146, 2385-2394. 
Zeigler, D. R. (2003). Gene sequences useful for predicting relatedness of whole genomes in bacteria. Int J Syst Evol Microbiol 53, 1893-1900.
Ziemke, F., Höfle, M. G., Lalucat, J. \& Rosselló-Mora, R. (1998). Reclassification of Shewanella putrefaciens Owen's genomic group II as Shewanella baltica sp. nov. Int J Syst Bacteriol 48, 179-186. 